\title{
Peran Literasi Komunikasi Pada Suatu Komunitas
}

Indrya Mulyaningsih

IAIN Syekh Nurjati Cirebon

indrya_m@yahoo.com

\begin{abstract}
Abstrak
Perkembangan teknologi membawa perubahan besar dalam berkomunikasi. Salah satu perkembangan tersebut adalah komunikasi daring, seperti WhatsApp Messenger atau sering disingkat dengan WA. Grup WA pada dasarnya adalah sama dengan diskusi atau seminar yang berfokus pada tema tertentu dengan beberapa pakar sebagai narasumber serta memiliki admin sebagai moderator. Di grup ini terdapat permasalahan yang dibahas, ditemukan solusi, serta diterapkan. Perbedaan mendasar pada bahasa yang digunakan. Jika seminar menggunakan media lisan, maka WA menggunakan media tulis. Peserta atau anggota pastilah memiliki minat terhadap permasalahan yang dibahas. Demi kelancaran komunikasi dalam berdiskusi, diperlukan kemampuan literasi para peserta atau anggotanya. Kelancaran bukan hanya pada penyampaian informasi, tetapi juga pada keberterimaan pesan serta tidak menyinggung perasaan peserta atau anggota lain. Oleh karena itu, anggota WA perlu meningkatkan diri dengan terus membaca, baik membaca teks yang tertulis maupun membaca konteks yang tidak tertulis.
\end{abstract}

The development of technology brings great changes in communicating. One such development is online communication, such as WhatsApp Messenger or often abbreviated as WA. The WA group is essentially the same as a discussion or seminar that focuses on a particular theme with some experts as resource persons and has an admin as a moderator. In this group there are problems discussed, solutions found, and applied. The fundamental difference in the language used. If the seminar uses oral media, then WA uses written media. Participants or members must have an interest in the issues discussed. For the sake of smooth communication in a discussion, required literacy ability of the participants or members. Smoothness is not only in the delivery of information but also on the acceptance of the message and does not offend the participants or other members. Therefore, WA members need to improve themselves by continuing to read, either reading the written text or reading the unwritten text.

Kata Kunci: budaya, komunikasi, komunitas, literasi, WhatsApp Messenger

\section{Pendahuluan}

Komunikasi merupakan aktivitas menyampaikan informasi dari satu pihak kepada pihak lain (Parikh, 2000), baik secara individu maupun berkelompok. Komunikasi berfungsi sebagai aktualisasi diri (Hartley, 1996) yang dilakukan secara sadar (Zamroni, 2009). Berdasarkan jumlah yang terlibat, komunikasi dapat dibedakan antara individu 
dan kelompok. Komunikasi individu hanya melibatkan satu individu dengan individu lain. Komunikasi kelompok melibatkan satu individu dengan beberapa individu lain. Dalam komunikasi individu hanya melibatkan dua individu secara intens sedangkan komunikasi kelompok melibatkan beberapa individu dalam waktu yang sama.

Komunikasi dapat dibedakan atas komunikasi verbal dan komunikasi nonverbal. Komunikasi verbal lebih banyak menggunakan simbol-simbol bahasa sedangkan nonverbal kebalikannya. Hasil penelitian menunjukkan bahwa $80 \%$ dalam komunikasi didominasi oleh faktor nonverbal (Ramadanty, 2014). Hal ini dikarenakan keterbatasan kata dalam menyampaikan maksud, makna kata yang ambigu, serta adanya penafsiran. Oleh karena itu, keberhasilan komunikasi verbal sangat dipengaruhi oleh faktor: inteligensi, budaya, pengetahuan, kepribadian, biologis, dan pengalaman.

Literasi merupakan kemampuan yang dimiliki individu dalam membaca teks maupun konteks serta menggunakannya dalam kehidupan sehari-hari (Education Development Center dalam Syahid, 2017). Literasi juga disinonimkan dengan melek huruf yang artinya, terampil secara kognitif, membaca, dan menulis, baik berupa teks maupun konteks (UNESCO, 2006). Literasi juga dimaknai sebagai praktik dan interaksi sosial yang berhubungan dengan pengetahuan, bahasa, dan budaya (Teguh, 2017).

Salah satu bentuk komunikasi verbal yang banyak digunakan adalah WhatsApp Messenger atau WA. Layaknya komunikasi lain, komunikasi melalui WA juga dilakukan secara individu dan kelompok. Salah satu faktor keberhasilan dalam berkomunikasi adalah literasi. Oleh karena itu, tulisan ini akan mengupas keterkaitan literasi dalam komunikasi kelompok di grup WA.

\section{Pembahasan}

Perkembangan teknologi membawa perubahan besar dalam berkomunikasi. Salah satu perkembangan tersebut adalah komunikasi daring, seperti WhatsApp Messenger atau sering disingkat dengan WA. WA merupakan salah satu aplikasi berbasis internet yang dapat digunakan untuk berbagai hal dalam berkomunikasi, baik pesan tulis, gambar, video, maupun dokumen. WA dapat bersifat pribadi dan grup. WA bersifat pribadi berfungsi hanya kepada satu tujuan. Adapun grup WA memiliki maksimal 256 anggota. Segala informasi yang dibagikan di grup WA dapat dibaca dan diketahui oleh seluruh anggota. 
Semakin banyak jumlah anggota, tentu saja semakin banyak juga komentar, tanggapan, atau pernyataan yang disampaikan. Belum lagi jika informasi awal sudah tertimpa oleh informasi yang lain. Misalnya, anggota pertama mengirim sebuah informasi. Anggota kedua memberi tanggapan. Ternyata anggota ketiga justru memberi tanggapan informasi yang sudah dibagikan oleh anggota pertama pada dua hari yang lalu. Tentu saja hal ini akan menindih informasi yang dikirim oleh anggota pertama. Belum lagi anggota ke-4 sampai ke-256. Belum lagi jika grup WA tersebut sangat aktif. Dalam satu jam tidak dibuka, pesan dapat menumpuk sampai 100-an.

Terdapat dua tipe anggota dalam menanggapi pesan yang bertumpuk tersebut. Pertama, membaca satu per satu walaupun memerlukan banyak waktu. Kedua, tidak dibaca dan langsung membaca pesan bagian akhir. Komunikasi di WA sifatnya tidak terputus, melainkan sambung-menyambung. Sekali tidak mengetahui informasi yang sedang dibahas maka tidak akan dapat memahami hal yang sedang dikomunikasikan. Hal seperti ini dapat menyebabkan komunikasi yang tidak lancar sehingga berpengaruh pada diskusi-diskusi berikutnya.

Bahkan tidak jarang, ketidaklancaran informasi dalam berkomunikasi menyebabkan beberapa anggota merasa jengkel, marah, atau tidak sabar. Hal ini menyebabkan grup tidak kondusif. Adapun permasalahan tersebut sebenarnya lebih disebabkan karena kurangnya literasi para anggota grup WA tersebut. Hal ini dapat diibaratkan dengan ketika mengikuti seminar. Dalam sebuah seminar, moderator memberi waktu kepada peserta untuk bertanya. Penanya pertama, kedua, dan ketiga tidak ada masalah. Masalah muncul pada peserta keempat karena pertanyaan yang diajukan sama dengan pertanyaan pertama. Hal ini terjadi karena peserta tersebut tidak menyimak atau tidak melakukan literasi.

Demikian halnya dengan komunikasi di grup WA. Acap kali anggota menanyakan hal yang sama. Tentu saja keadaan ini akan membuat anggota lain menjadi tidak nyaman. Seharusnya, anggota grup WA selalu menyimak berbagai informasi, baik pertanyaan maupun pernyataan. Anggota grup jangan malas untuk membuka, membaca, serta memahami pesan yang sudah lewat atau sudah dikirimkan oleh anggota lain. Walaupun tertumpuk banyak, setiap anggota harus mau membaca. Jika telah dibaca dan belum mengerti, barulah bertanya.

Demi menjaga komunikasi, hendaknya para anggota menerapkan atau menggunakan kemampuan literasi yang dimiliki. Seperti telah diuraikan di atas bahwa 
keberhasilan dalam berkomunikasi ditentukan oleh banyak faktor. Inteligensi atau kecerdasan sangat memengaruhi keberhasilan dalam berkomunikasi. Semakin cerdas seseorang, semakin cepat dalam menangkap makna atau maksud yang disampaikan. Salah satu bentuk kecerdasan dapat diketahui dari tanggapan yang diberikan berupa diksi yang digunakan. Semakin cerdas seseorang, semakin bernas kata-kata yang digunakan.

Budaya juga turut memengaruhi dalam berkomunikasi. Budaya yang dimaksud adalah membaca. Anggota dari sebuah grup hendaknya memiliki budaya baca yang tinggi. Artinya, setiap anggota harus mau dan harus meluangkan waktu untuk membaca serta menyimak pesan-pesan sebelumnya. Berdasarkan pengamatan, anggota cenderung malas untuk membaca. Alasannya pun beragam, seperti: tidak ada waktu, buru-buru, dan yang paling sering adalah malas. Anggota yang seperti ini lebih suka mendengar penjelasan dari orang lain. Padahal informasi yang diperoleh dengan membaca langsung dan penjelasan orang kedua sangat berbeda.

Pengetahuan juga turut berperan dalam komunikasi di grup WA. Semakin luas pengetahuan yang dimiliki seseorang, semakin cepat juga menangkap dan memahami informasi. Oleh karena itu, para anggota hendaknya belajar yang terkait dengan fokus grup tersebut. Setidaknya belajar terkait hal-hal atau informasi mendasar supaya dapat cepat menangkap informasi. Berdasarkan pengalaman dan pengamatan, anggota yang nol pengetahuan akan cenderung hanya sebagai pelengkap atau pemenuh jumlah anggota di grup WA. Anggota yang seperti ini sangat tidak produktif dan justru akan menghambat orang lain yang ingin bergabung.

Meskipun komunikasi ini mengandalkan bahasa, tetapi faktor kepribadian tetap berandil. Kata mutiara menyatakan bahwa bahasa menunjukkan bangsa. Bahasa yang digunakan oleh seseorang menunjukkan kepribadian atau karakter. Oleh karena itu, komunikasi di grup WA juga harus memerhatikan hal tersebut. Seseorang dengan kepribadian yang baik pasti juga akan menggunakan bahasa atau diksi yang baik. Artinya, alangkah lebih baik jika anggota grup WA berhati-hati dalam memberi komentar atau tanggapan. Sila dibaca ulang sebelum sebuah tanggapan atau pernyataan dikirim ke grup. Hal ini untuk mengantisipasi berbagai hal yang tidak diinginkan.

Faktor lain yang turut berpengaruh adalah biologis. Adapun faktor biologis dalam komunikasi di grup WA adalah jari. Berdasarkan pengamatan, seseorang yang menggunakan gawai kecil acap kali salah dalam menekan tombol. Misalnya, bermaksud 
menekan atau menulis huruf 'd', tetapi yang tertulis malah huruf 's'. Hal ini sama halnya dengan ketika seseorang akan mengucapkan 'kabur', tetapi karena cadel sehingga yang terucap 'kabul'. Kejadian seperti ini tentu saja akan mengganggu dalam berkomunikasi. Karena cadel merupakan kelainan, kesalahan demikian dapat diterima. Fenomena ini berbeda dengan tulisan. Sebuah tulisan dapat diedit dan diperbaiki sebelum disampaikan atau diunggah.

Selain faktor jari, faktor biologi lainnya adalah pada gawai yang digunakan. Pernah pada suatu hari, ada pesan masuk yang bertuliskan 'S4L4M'. Tulisan ini tentu saja terkesan aneh, lucu, dan gaul. Pasti banyak penafsiran yang muncul dari penggunaan huruf pada tulisan tersebut. Setelah dikonfirmasi kepada pemilik tulisan tersebut, ternyata huruf 'A' pada gawai rusak dan tidak berfungsi sehingga digunakanlah angka 4 sebagai penggantinya. Meski terkesan sepele, tetapi sempat membuat komunikasi menjadi tidak nyaman.

Pengalaman seseorang juga turut berpengaruh terhadap keberhasilan komunikasi. Semakin berpengalaman, seseorang akan semakin berhati-hati dalam memberi komentar, pendapat, atau tanggapan.

Layaknya diskusi dalam sebuah seminar yang menghendaki hadirnya moderator, di grup WA juga memerlukan moderator. Moderator di grup WA biasa disebut dengan admin, sebagai kependekan dari administrasi. Peran admin sama dengan moderator.

Komunikasi di WA bukan hanya sekadar basa-basi yang tidak bertujuan. Sebuah grup dibentuk pasti karena ada persamaan tujuan yang ingin dicapai. Para anggota hendaknya memiliki ilmu pengetahuan yang terkait dengan grup tersebut, walaupun hanya sedikit. Kemampuan ini perlu dimiliki terkait dengan istilah atau kosakata yang digunakan dalam berkomunikasi. Oleh karena itu, inteligensi turut berperan dalam komunikasi di grup WA.

\section{Simpulan}

Grup WA pada dasarnya adalah sama dengan diskusi atau seminar yang berfokus pada tema tertentu dengan beberapa pakar sebagai narasumber serta memiliki admin sebagai moderator. Di grup ini terdapat permasalahan yang dibahas, ditemukan solusi, serta diterapkan. Perbedaan mendasar pada bahasa yang digunakan. Jika seminar menggunakan media lisan, maka WA menggunakan media tulis. Peserta atau anggota pastilah memiliki minat terhadap permasalahan yang dibahas. Demi kelancaran 
komunikasi dalam berdiskusi, diperlukan kemampuan literasi para peserta atau anggotanya. Kelancaran bukan hanya pada penyampaian informasi, tetapi juga pada keberterimaan pesan serta tidak menyinggung perasaan peserta atau anggota lain. Oleh karena itu, marilah meningkatkan diri dengan terus membaca, baik membaca teks tertulis maupun membaca teks yang tidak tertulis.

\section{Ucapan Terima Kasih}

Terima kasih kepada Dr. Dasapta Erwin Irawan, S.T., M.T., Nuning Kurniasih, M.Si., serta teman-teman di grup WA 'Scopus WoS OSF Conf.'atas ide dan ilmu yang sudah dibagikan.

\section{Daftar Pustaka}

Hartley, Peter. (1996). Interpersonal Communication. Canada: Routledge.

Parikh, Prashant. (2000). Linguistics and Philosophy. Netherlands: Kluwer Academic Publishers.

Ramadanty, Sari. (2014). "Penggunaan Komunikasi Fatis dalam Pengelolaan Hubungan di Tempat Kerja” pada Jurnal Ilmu Komunikasi, Volume 5, Nomor 1, Maret 2014, hlm. 1-12.

Syahid, Achmad Saifullah. (2017). "Hati-hati Mengartikan, Gerakan Literasi Bukan Sekadar Gerakan Baca dan Tulis” dalam Kompasiana, 2 Maret 2017.

Teguh, Mulyo. (2017). “Aktualisasi Kurikulum 2013 di Sekolah Dasar melalui Gerakan Literasi Sekolah untuk Menyiapkan Generasi Unggul dan Berbudi Pekerti” Dalam Prosiding Seminar Nasional 15 Maret 2017, hal. 18-26 di http://pgsd.umk.ac.id/files/prosiding/2017/3\%20Mulyo\%20Teguh.pdf.

UNESCO. (2006). Education for All Global Monitoring Report.

Zamroni, Mohammad. (2009). Filsafat Komunikasi: Pengantar Ontologis, Epistemologis, Aksiologis. Yogyakarta: Graha Ilmu. 